\title{
Bacterial Community Associated with Healthy and Diseased Reef Coral Mussismilia hispida from Eastern Brazil
}

\author{
Alinne Pereira de Castro • Samuel Dias Araújo Jr • Alessandra M. M. Reis • \\ Rodrigo L. Moura • Ronaldo B. Francini-Filho • Georgios Pappas Jr • \\ Thiago Bruce Rodrigues • Fabiano L. Thompson • Ricardo H. Krüger
}

Received: 30 November 2009 / Accepted: 14 February 2010/Published online: 30 March 2010

(C) Springer Science+Business Media, LLC 2010

\begin{abstract}
In order to characterize the bacterial community diversity associated to mucus of the coral Mussismilia hispida, four 16S rDNA libraries were constructed and 400 clones from each library were analyzed from two healthy colonies, one diseased colony and the surrounding water. Nine
\end{abstract}

Alinne Pereira de Castro and Samuel Dias Araújo Jr. contributed equally to this work.

Electronic supplementary material The online version of this article (doi:10.1007/s00248-010-9646-1) contains supplementary material, which is available to authorized users.

A. P. de Castro $\cdot$ R. H. Krüger $(\bowtie)$

Laboratorio de Enzimologia, Departamento de Biologia Celular, Universidade de Brasilia,

Brasilia, Distrito Federal, Brasil

e-mail: kruger@unb.br

S. D. Araújo Jr • A. M. M. Reis • G. Pappas Jr

Universidade Católica de Brasilia - UCB,

CAMPUS II-SGAN Quadra 916 Avenida W5 Norte,

Modulo C-Sala 210,

Brasilia DF-CEP 70790-160, Brazil

\section{R. L. Moura}

Conservation International Brazil,

Marine Program, Rua das Palmeiras 451,

45900-000 Caravelas, Bahia, Brazil

\section{R. B. Francini-Filho}

Institute of Biology, State University of Paraiba (UEPB),

Paraiba, Brazil

\section{G. Pappas Jr}

EMBRAPA genetic resources and biotechnology,

Brasilia, Distrito Federal, Brazil 70770-900

T. B. Rodrigues $\cdot$ F. L. Thompson

Department of Genetics, Institute of Biology,

Federal University of Rio de Janeiro (UFRJ),

Rio de Janeiro, Brazil bacterial phyla were identified in healthy $M$. hispida, with a dominance of Proteobacteria, Actinobacteria, Acidobacteria, Lentisphaerae, and Nitrospira. The most commonly found species were related to the genera Azospirillum, Hirschia, Fabibacter, Blastochloris, Stella, Vibrio, Flavobacterium, Ochrobactrum, Terasakiella, Alkalibacter, Staphylococcus, Azospirillum, Propionibacterium, Arcobacter, and Paenibacillus. In contrast, diseased M. hispida had a predominance of one single species of Bacteroidetes, corresponding to more than $70 \%$ of the sequences. Rarefaction curves using evolutionary distance of $1 \%$ showed a greater decrease in bacterial diversity in the diseased $M$. hispida, with a reduction of almost $85 \%$ in OTUs in comparison to healthy colonies. $\int$-Libshuff analyses show that significant $p$ values obtained were $<0.0001$, demonstrating that the four libraries are significantly different. Furthermore, the sympatric corals M. hispida and Mussismilia braziliensis appear to have different bacterial community compositions according to Principal Component Analysis and Lineage-specific Analysis. Moreover, lineages that contribute to those differences were identified as $\alpha$-Proteobacteria, Bacteroidetes, and Firmicutes. The results obtained in this study suggest hostmicrobe co-evolution in Mussismilia, and it was the first study on the diversity of the microbiota of the endemic and endangered of extinction Brazilian coral M. hispida from Abrolhos bank.

\section{Introduction}

The brain coral Mussismilia is the most important reef builder of the Abrolhos reef bank, comprising for approximately $70 \%$ of the reef structures [1]. This is the largest and most important reef bank of the entire South Atlantic Ocean (Electronic Supplementary Material, Fig. S1) [2]. 
The genus Mussismilia comprises three species (M. braziliensis, $M$. hispida, and $M$. hartii) with different morphologies and genotypes [3, 4], while $M$. harttii presents a very distinct morphology, M. hispida and braziliensis present subtle differences (small colonies may be even difficult to differentiate in the field). Mussismilia braziliensis forms hemispheric large colonies ( $>2 \mathrm{~m}$ in diameter), consisting of small polips (10 $\mathrm{mm}$ in diameter), whereas M. hispida forms smaller colonies $(<1 \mathrm{~m}$ in diameter) and larger polyps ( $>15 \mathrm{~mm}$ in diameter) [2]. The two species are sympatric in the Abrolhos bank, but the former species occurs only in the Bahia state, while the latter is found from Maranhão to Santa Catarina states (ca. 7,000 km distance). This wide latitudinal distribution reflects a high physiological plasticity of $M$. hispida, particularly related to water quality and temperature tolerance [2]. The Mussismilia host harbors a high number of microbes, yet it is not known whether different Mussismilia species have different microbiotas [5]. The microbial communities from closely related species of the genus Acropora are very similar in corals colonies from the same location, arguing against the classical idea of host-microbe co-evolution in corals $[6,7]$.

Reef corals are in danger of extinction worldwide [810]. Mass mortality of Mussismilia has been recently documented for the Abrolhos bank [11]. Global climate changes and infectious diseases appear to be the main causes of mass mortality of Mussismilia. There is evidence that diseases are more common in the (late) summer than in the winter and that disease incidence is higher in the more human impacted areas [11]. White plague is one of the most common diseases in the Abrolhos bank, although bleaching is also observed in the Corumbau reef. So far, the microbial aetiological agents of these diseases in the Abrolhos Bank have not been determined.

One possible function of microorganisms found on coral holobiont surfaces may be to provide the corals with protection from pathogens by means of interspecific competition and/or secretion of antibiotic substances $[6,7$, $12,13]$. These microorganisms may also supply the coral with nitrogen and phosphorous, which are not provided by their symbiotic zooxanthellae [14-19]. Hence, changes in microbial communities may affect coral health [20]. The role of bacteria on coral health is not yet fully understood $[21,22]$. In the first culture-independent study on the bacterial community diversity associated with the Brazilian endemic coral species M. braziliensis, the classes Proteobacteria, Cyanobacteria, and unclassified Bacteria appeared to be dominant in the mucus [23]. Diseased and healthy colonies of $M$. braziliensis had distinct microbiotas, although there was not a clear dominance of a potential aetiological disease agent in the diseased M. braziliensis. Because there was no dominance of a particular taxonomic group, it was difficult to pinpoint possible disease agents on that study. Diseased M. braziliensis had a highly heterogeneous bacterial microbiota with most of its $16 \mathrm{~S}$ rDNA sequences appearing as singletons, suggesting that the disruption of holobiont homeostasis resulted in colonization by a diverse group of opportunistic bacteria [23].

The aim of this study was to analyze the bacterial community diversity associated with apparently healthy and diseased (paling and necrosis) colonies of $M$. hispida based on 16S rRNA clone libraries. Statistical analyses allowed the comparison between 16S rRNA libraries obtained from M. hispida and M. braziliensis in order to disclose possible host specific microbiotas.

\section{Materials and Methods}

\section{Site and Sample Collection}

Colonies of apparently healthy and diseased (paling and necrosis) M. hispida were collected on 03/April/2007 at the AMP3 site, Itacolomis Reef, Corumbau village (16 55' 02, 3" S, 39 04' 39,4" W; (Electronic Supplementary Material, Fig. S1) by SCUBA diving between depths of 7 and $10 \mathrm{~m}$. Sea water $(1 \mathrm{~L})$ of the site was collected in order to measure the water quality physical-chemical parameters [24] (Electronic Supplementary Material, Fig. S3).

\section{Mucus and Water Sampling}

The coral mucus was drained from colonies of M. hispida using a sterile syringe on board the boat. The mucus samples were placed in sterile flasks. These samples were immediately placed in an ice box and brought to the laboratory for further extraction of total DNA. RNA later (Qiagen; proportion 1:1) was used in order to avoid nucleic acid degradation of mucus bacteria. Sea water of the surrounding environment near the corals was collected in a sterile bottle. One liter of sea water was pre-filtered through an $8.0 \mu \mathrm{m}$ filter and vacuum filtered through a $0.2 \mu \mathrm{m}$ membrane (Durapore, Millipore). The membrane was subsequently placed in $4 \mathrm{ml}$ of lysis buffer $(40 \mathrm{mM}$ EDTA, $50 \mathrm{mM}$ tris- $\mathrm{HCl}, 0.75 \mathrm{M}$ sucrose) and kept on ice until DNA extraction was performed.

\section{DNA Extraction}

DNA was extracted from mucus of two apparently healthy colonies of $M$. hispida and one diseased colony (paling and necrosis) approximately $5 \mathrm{~m}$ apart. The diseased colony was completely infected. The mucus DNA extraction was performed as described by Reis et al. [23]. The water DNA was extracted from the filter using the protocol by Schauer et al. [25] as described in Reis et al. [23]. 
16S rRNA Amplification, Cloning, and Sequencing

Total purified DNA from the four samples (one from water, two from healthy coral, and one from diseased coral mucus) were used as templates for amplification of the 16S rRNA gene using the universal primer 1492R (5'-TAC GGY TAC CTT GTT ACG ACT T-3') and the domain Bacteria-specific primer 27F (5'-AGA GTT TGA TCM TGG CTC AG-3'). The PCR reactions and the construction of the four $16 \mathrm{~S}$ rRNA libraries were performed as described in Reis et al. [23].

\section{Sequence Analysis}

Sequence quality was checked using the tool available at the site http://www.bioinformatica.ucb.br/electro.html [26] and chimeras were detected using the Chimera-check software at the Ribosomal Database Project (RDP) home page [27]. Trimmed sequences of each library were aligned using Muscle [28] and the alignment was manually edited using Bioedit (http://www.mbio.ncsu.edu/BioEdit/). The hipervariable regions generating unsolvable gaps were clipped out and sequences shorter than 370 bp were removed from the analysis. Jukes-Cantor evolutionary distances were calculated using DNADIST of the PHYLIP 3.63 package (http://evolution.genetics.washington.edu/ phylip/getme.html). Aligned sequences were clustered into operational taxonomic units (OTUs) using DOTUR [29]. This software was also used to calculate diversity indices, richness estimators and to construct randomized rarefaction curves. Phylogenetic analyses were performed with the software MEGA [30], using $p$ distance model [31].

$16 \mathrm{~S}$ rRNA sequence data of $M$. braziliensis [23] and $M$. hispida and the two corresponding surrounding water samples were compared using UniFrac, a web application available at http://bmf.colorado.edu/unifrac [32]. M. braziliensis [23] and M. hispida were collected on the same date and site described above. Sequences from both species were aligned using Muscle [28]. Phylogenetic trees based on the $\mathrm{p}$ distance model were constructed using MEGA software [30]. Sequence data were also analyzed using Principal Component Analysis (PCA) [33] and Lineagespecific Analysis. The PCA Lineage-specific Analysis with the branch length threshold of 0.15 was obtained from Unifrac software [32].

$\int$-LIBSHUFF software was used to estimate the significance of differences between the libraries of seawater, $M$. hispida and healthy colonies of M. braziliensis [34]. The Classifier tool at the Ribosomal Database Project RDP and BLASTN were used to assign the $16 \mathrm{~S}$ rRNA sequences from M. braziliensis to taxonomic levels [35, 36]. The confidence threshold was 95\%. Sequence Match was used to find the closest type of each cluster. Sequence data generated in this study are available at GenBank under the accession numbers GU199606-GU200660.

\section{Results}

One thousand and forty-eight high quality $16 \mathrm{~S}$ rRNA sequences were obtained in this study. The majority of the sequences from water ( $92 \%$ of the total) were related at species level (i.e., $>97 \%$ sequence similarity) to sequences already deposited in the GenBank. Between $72 \%$ and $80 \%$ of the sequences of the healthy coral mucus had more than $97 \%$ sequence similarity to GenBank sequences, whereas $99 \%$ of the sequences of the diseased coral mucus showed $97-100 \%$ similarity with the sequences deposited in this database (Electronic Supplementary Material, Fig. S2). Using the Classifier (RDP) with a confidence threshold of $95 \%$, five bacterial phyla were identified in water, eight and nine phyla in each of the healthy colonies and three phyla in the diseased coral (Fig. 1). Unclassified bacteria were
Figure 1 Frequency of bacterial phylum found in the mucus coral and surrounding water according to ribosomal data project with $95 \%$ confidence threshold. ( $\square$ water; $\square$ healthy $\mathrm{MH} 2$; $\square$ healthy MH4;

diseased)

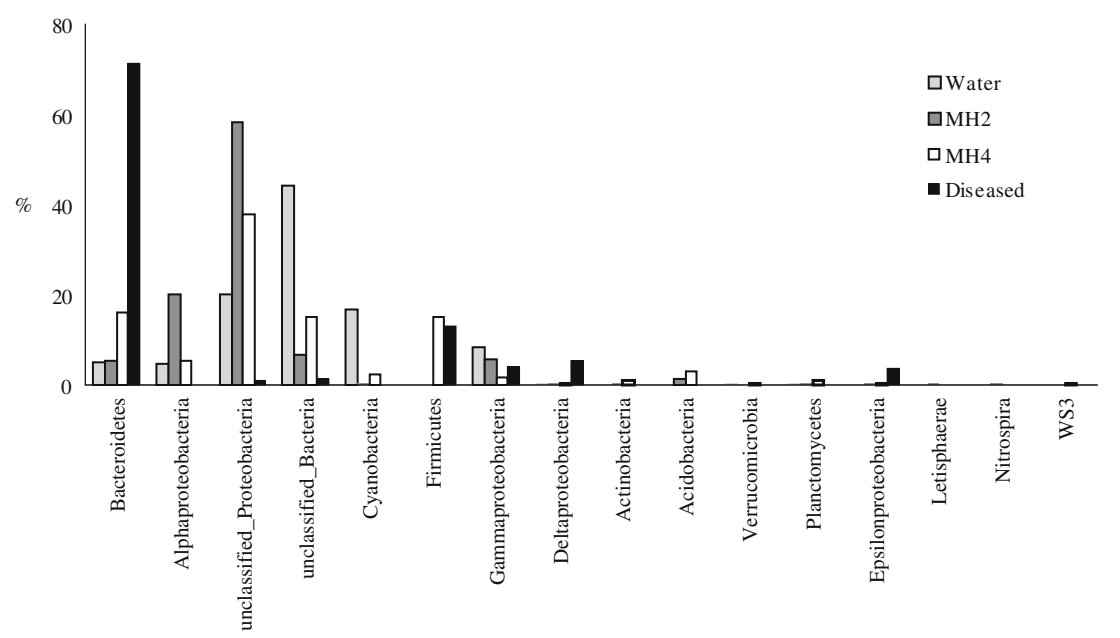


Table 1 Dominant bacterial clusters found in the water and coral mucus

\begin{tabular}{|c|c|c|c|c|c|c|}
\hline Water & $\begin{array}{l}\text { Number of } \\
\text { sequences }\end{array}$ & $\begin{array}{l}\text { Representative } \\
\text { sequence } \\
\text { (Accession no.) }\end{array}$ & $\begin{array}{l}\text { Closest neighbor } \\
\text { (\% similarity) }\end{array}$ & $\begin{array}{l}\text { Accession no. of } \\
\text { closest neighbor }\end{array}$ & $\begin{array}{l}\text { Closest cultured neighbor } \\
(\% \text { similarity) }\end{array}$ & $\begin{array}{l}\text { Accession no. } \\
\text { of closest } \\
\text { neighbor }\end{array}$ \\
\hline W1 & 18 & 7H2O_PL1 & $\begin{array}{l}\text { Uncultured marine bacterium } \\
\text { (99) }\end{array}$ & FJ895254.1 & $\begin{array}{l}\text { Prochlorococcus marinus subsp. } \\
\text { pastoris }(\mathrm{T}) ;(96)\end{array}$ & AF180967 \\
\hline W2 & 7 & 36H2O_PL1 & $\begin{array}{l}\text { Uncultured bacterium clone } \\
\text { 6C232539 (99) }\end{array}$ & EU804590.1 & Bartonella alsatica $(\mathrm{T}) ;(84)$ & AJ002139 \\
\hline W3 & 42 & 19H2O_PL1 & Uncultured bacterium (99) & EF572981.1 & Rhizobium giardinii $(\mathrm{T}) ;(84)$ & U86344 \\
\hline W4 & 11 & 26H2O_PL1 & Uncultured bacterium (99) & EU805158.1 & $\begin{array}{l}\text { P. marinus subsp. pastoris }(\mathrm{T}) \text {; } \\
\text { (97) }\end{array}$ & AF180967 \\
\hline W5 & 4 & 43H2O_PL1 & $\begin{array}{l}\text { Uncultured gamma } \\
\text { proteobacterium clone } \\
\text { D03-W3-C2 (99) }\end{array}$ & EU315646.1 & Kangiella koreensis (T); (90) & AY520560 \\
\hline W6 & 4 & 32H2O_PL1 & $\begin{array}{l}\text { Uncultured alpha } \\
\text { proteobacterium clone } \\
\text { HF10_24P22 (99) }\end{array}$ & EU361495 & Stella vacuolata $(\mathrm{T}) ;(88)$ & AJ535711 \\
\hline W7 & 6 & 34H2O_PL1 & $\begin{array}{l}\text { Uncultured bacterium clone } \\
\text { W2-D09 (99) }\end{array}$ & FJ930688.1 & Anabaena cylindrica $(\mathrm{T}) ;(82)$ & AF091150 \\
\hline W8 & 8 & 13H2O_PL1 & $\begin{array}{l}\text { Uncultured cyanobacterium } \\
\text { clone } 5 \mathrm{kp} 12 \mathrm{D} 12 \text { (99) }\end{array}$ & EF092507.1 & Chlorogloeopsis fritschii (T); (84) & AB093489 \\
\hline W9 & 11 & 37H2O_PL1 & $\begin{array}{l}\text { Uncultured gamma } \\
\text { proteobacterium clone D03- } \\
\text { W3-C4 (99) }\end{array}$ & EU315485.1 & K. koreensis $(\mathrm{T}) ;(87)$ & AY520560 \\
\hline W10 & 7 & 33H2O_PL1 & Vibrio sp. NH87-56 (99) & GQ336803.1 & Vibrio neptunius (T); (99) & AJ316171 \\
\hline W11 & 5 & 82H2O_PL2 & $\begin{array}{l}\text { Uncultured gamma } \\
\text { proteobacterium clone } \\
\text { SHWN (99) }\end{array}$ & FJ745243.1 & $\begin{array}{l}\text { Thalassolituus oleivorans }(\mathrm{T}) \text {; } \\
\text { (86) }\end{array}$ & AJ431699 \\
\hline W12 & 3 & 36H2O_PL2 & $\begin{array}{l}\text { Uncultured bacterium clone } \\
\text { 4C230061 (99) }\end{array}$ & EU802699.1 & S. vacuolata (T); DSM5901; (88) & AJ535711 \\
\hline W13 & 3 & 71H2O_PL4 & $\begin{array}{l}\text { Uncultured gamma proteobacterium } \\
\text { clone HF10 (99) }\end{array}$ & EU361666.1 & Microbulbifer maritimus (T); (90) & AY377986 \\
\hline W14 & 22 & 59H2O_PL2 & $\begin{array}{l}\text { Uncultured marine bacterium } \\
\text { clone SW2-44-8F (99) }\end{array}$ & FJ895263.1 & Conexibacter woesei $(\mathrm{T}) ;(82)$ & AJ440237 \\
\hline W15 & 7 & 76H2O_PL4 & $\begin{array}{l}\text { Uncultured bacterium clone } \\
\text { MM54 (99) }\end{array}$ & FJ809096.1 & Ruegeria pomeroyi $(\mathrm{T}) ;(94)$ & AF098491 \\
\hline W16 & 3 & 2H2O_PL2 & $\begin{array}{l}\text { Uncultured alpha } \\
\text { proteobacterium clone } \\
\text { WW01G11 (99) }\end{array}$ & EF630000.1 & Labrenzia aggregata $(\mathrm{T}) ;(88)$ & D88520 \\
\hline W17 & 4 & 91H2O_PL1 & $\begin{array}{l}\text { Uncultured bacterium clone } \\
\text { 6C233081 (99) }\end{array}$ & EU805095.1 & $\begin{array}{l}\text { Sulfurospirillum arcachonense } \\
\text { (T); (91) }\end{array}$ & Y11561 \\
\hline \multicolumn{7}{|c|}{ MH2 Healthy } \\
\hline H1 & 51 & 10MH2_PL2 & $\begin{array}{l}\text { Uncultured alpha } \\
\text { proteobacterium clone } \\
\text { CD204D02 (98) }\end{array}$ & DQ200435.1 & Azospirillum brasilense (T); (86) & AY150046 \\
\hline $\mathrm{H} 2$ & 126 & 10MH2_PL4 & $\begin{array}{l}\text { Uncultured bacterium clone } \\
\text { SGUS430 (98) }\end{array}$ & FJ202840.1 & $\begin{array}{l}\text { Hirschia baltica (T); IFAM } 1418 \\
\quad(85)\end{array}$ & X52909 \\
\hline $\mathrm{H} 3$ & 11 & 11MH2_PL2 & $\begin{array}{l}\text { Uncultured bacterium clone } \\
\text { SHFH448 (96) }\end{array}$ & FJ203413.1 & Fabibacter halotolerans $(\mathrm{T}) ;(87)$ & DQ080995 \\
\hline $\mathrm{H} 4$ & 3 & 13MH2_PL4 & $\begin{array}{l}\text { Uncultured bacterium clone } \\
\text { C3D10-2 (96) }\end{array}$ & FJ930404.1 & Blastochloris sulfoviridis (T); (91) & D86514 \\
\hline H5 & 4 & 14MH2_PL4 & $\begin{array}{l}\text { Marine magnetic spirillum } \\
\text { QH-2 (87) }\end{array}$ & EU675666.1 & S. vacuolata $(\mathrm{T}) ;(84)$ & AJ535711 \\
\hline H6 & 4 & 28MH2_PL4 & Uncultured Vibrio sp. (99) & AM183716.1 & Vibrio nereis $(\mathrm{T}) ;(98)$ & X74716 \\
\hline \multicolumn{7}{|c|}{ MH4 Healthy } \\
\hline M1 & 28 & 50MH4_PL4 & $\begin{array}{l}\text { Uncultured Bacteroidetes } \\
\text { bacterium clone CD205C10 } \\
\text { (95) }\end{array}$ & DQ200521.1 & Flavobacterium frigoris $(\mathrm{T}) ;(84)$ & AJ557887 \\
\hline M2 & 15 & 81MH4_PL4 & $\begin{array}{l}\text { Uncultured alpha } \\
\text { proteobacterium clone } \\
\text { CL20-G04 (98) }\end{array}$ & GQ204833.1 & Ochrobactrum tritici $(\mathrm{T}) ;(92)$ & AJ242584 \\
\hline M3 & 84 & 69MH4_PL4 & Uncultured alpha & DQ889887.1 & Terasakiella pusilla $(\mathrm{T}) ;(91)$ & AB006768 \\
\hline
\end{tabular}


Table 1 (continued)

\begin{tabular}{|c|c|c|c|c|c|c|}
\hline Water & $\begin{array}{l}\text { Number of } \\
\text { sequences }\end{array}$ & $\begin{array}{l}\text { Representative } \\
\text { sequence } \\
\text { (Accession no.) }\end{array}$ & $\begin{array}{l}\text { Closest neighbor } \\
(\% \text { similarity })\end{array}$ & $\begin{array}{l}\text { Accession no. of } \\
\text { closest neighbor }\end{array}$ & $\begin{array}{l}\text { Closest cultured neighbor } \\
\text { (\% similarity) }\end{array}$ & $\begin{array}{l}\text { Accession no. } \\
\text { of closest } \\
\text { neighbor }\end{array}$ \\
\hline & & & $\begin{array}{l}\text { proteobacterium clone } \\
\text { EC154 (98) }\end{array}$ & & & \\
\hline M4 & 3 & 93MH4_PL4 & $\begin{array}{l}\text { Uncultured bacterium clone } \\
\text { KspoC6 (95) }\end{array}$ & EU035944.2 & $\begin{array}{l}\text { Alkalibacter saccharofermentans } \\
\text { (T); (82) }\end{array}$ & AY312403 \\
\hline M5 & 33 & 38MH4_PL4 & $\begin{array}{l}\text { Uncultured bacterium clone } \\
\text { nbw292b08c1 (99) }\end{array}$ & GQ086630.1 & Staphylococcus warneri $(\mathrm{T}) ;(99)$ & L37603 \\
\hline M6 & 3 & 26MH4_PL4 & $\begin{array}{l}\text { Uncultured alpha } \\
\text { proteobacterium clone } \\
\text { CD204D02 (99) }\end{array}$ & DQ200435.1 & A. brasilense $(\mathrm{T}) ;(89)$ & AY150046 \\
\hline M7 & 3 & 61MH4_PL4 & $\begin{array}{l}\text { Uncultured bacterium clone } \\
\text { nbw } 415 \mathrm{~g} 09 \mathrm{c} 1 \text { (99) }\end{array}$ & GQ092500.1 & $\begin{array}{l}\text { Propionibacterium avidum (T); } \\
\quad(94)\end{array}$ & AJ003055 \\
\hline M8 & 7 & 12MH4_PL2 & $\begin{array}{l}\text { Uncultured epsilon } \\
\text { proteobacterium clone } \\
\text { CH-B24 (88) }\end{array}$ & AY280389.1 & Arcobacter nitrofigilis $(\mathrm{T}) ;(84)$ & L14627 \\
\hline M9 & 7 & 79MH4_PL4 & Paenibacillus sp (98) & AB366300.1 & Paenibacillus koreensis (T); (96) & AF130254 \\
\hline M10 & 5 & 42MH4_PL1 & $\begin{array}{l}\text { Uncultured bacterium clone } \\
\text { SHFH635 (78) }\end{array}$ & FJ203563.1 & $\begin{array}{l}\text { Candidatus Phytoplasma ulmi (T); } \\
\text { (no significant similarity found) }\end{array}$ & AY197655 \\
\hline M11 & 7 & 24MH4_PL4 & $\begin{array}{l}\text { Uncultured bacterium clone } \\
\text { BB1S16SI-7 (99) }\end{array}$ & EF433151.1 & $\begin{array}{l}\text { Flavobacterium daejeonense }(\mathrm{T}) \text {; } \\
\quad(86)\end{array}$ & DQ222427 \\
\hline M12 & 3 & 35MH4_PL2 & $\begin{array}{l}\text { Uncultured bacterium clone } \\
\text { EPR3970 (95) }\end{array}$ & EU491660.1 & $\begin{array}{l}\text { Clostridium cylindrosporum }(\mathrm{T}) \text {; } \\
(80)\end{array}$ & Y18179 \\
\hline M13 & 3 & 14MH4_PL2 & Uncultured bacterium (99) & AB294987.1 & $\begin{array}{l}\text { Aphanizomenon flos-aquae (T); } \\
\text { (85) }\end{array}$ & AY038035 \\
\hline \multicolumn{7}{|c|}{ MH2 Diseased } \\
\hline D1 & 16 & 86MH2D_PL1 & Desulfovibrio sp. NA302 (99) & AJ866944.1 & $\begin{array}{l}\text { Desulfovibrio acrylicus (T); W218 } \\
\quad(98)\end{array}$ & U32578.1 \\
\hline D2 & 205 & 38MH2D_PL4 & Uncultured Bacteroidetes (99) & AY580708.1 & F. daejeonense (T); GH1-10 (86) & DQ222427 \\
\hline D3 & 8 & 54MH2D_PL3 & $\begin{array}{l}\text { Uncultured bacterium clone } \\
\text { SHFG542 (99) }\end{array}$ & FJ203140.1 & $\begin{array}{l}\text { Arcobacter halophilus (T); LA31B } \\
\quad \text { (92) }\end{array}$ & AF513455 \\
\hline D4 & 5 & 55MH2D_PL1 & $\begin{array}{l}\text { Uncultured bacterium clone } \\
\text { SHFG542 (99) }\end{array}$ & FJ203140.1 & A. nitrofigilis (T) (93) & L14627 \\
\hline D5 & 4 & 95MH2D_PL2 & $\begin{array}{l}\text { Uncultured bacterium clone } \\
\text { SHFG649 (100) }\end{array}$ & FJ203237.1 & $\begin{array}{l}\text { Pseudoalteromonas aurantia }(\mathrm{T}) \\
\text { ATCC } 33046 \mathrm{~T}(91)\end{array}$ & X82135 \\
\hline D6 & 4 & 29MH2D_PL2 & $\begin{array}{l}\text { Uncultured gamma } \\
\text { proteobacterium (99) }\end{array}$ & FJ654592.1 & $\begin{array}{l}\text { Oceanospirillum multiglobuliferum } \\
\text { (T); IFO } 13614 \text { (92) }\end{array}$ & AB006764 \\
\hline D7 & 3 & 89MH2D_PL1 & $\begin{array}{l}\text { Uncultured bacterium clone } \\
\text { SGUS484 (99) }\end{array}$ & FJ202184.1 & $\begin{array}{l}\text { Staphylococcus saccharolyticus } \\
\text { (T); (81) }\end{array}$ & L37602 \\
\hline D8 & 4 & 90MH2D_PL4 & Uncultured bacterium (99) & FJ202830.1 & $\begin{array}{l}\text { Clostridium proteolyticum }(\mathrm{T}) \text {; } \\
\text { DSM } 3090(92)\end{array}$ & $\mathrm{X} 73448$ \\
\hline D9 & 9 & 34MH2D_PL2 & Uncultured Clostridia (99) & EF629781.1 & $\begin{array}{l}\text { Clostridium glycolicum (T); CIN5 } \\
\text { (89) }\end{array}$ & AY007244 \\
\hline D10 & 11 & 19MH2D_PL4 & Uncultured bacterium (100) & FJ203165.1 & $\begin{array}{l}\text { Peptostreptococcus stomatis }(\mathrm{T}) \text {; } \\
\text { W2278 (86) }\end{array}$ & DQ160208 \\
\hline D11 & 13 & 60MH2D_PL1 & Uncultured bacterium (99) & FJ202903.1 & $\begin{array}{l}\text { Fusibacter paucivorans (T); SEBR } \\
4211 \text { (91) }\end{array}$ & AF050099 \\
\hline
\end{tabular}

predominant in water (44\%), followed by Proteobacteria (33\%), and Cyanobacteria (17\%). Proteobacteria dominated the microbiota of healthy colonies $(45-85 \%)$ where the great majority of them (40-60\% of total bacteria) were allocated to novel Proteobacteria clades. Actinobacteria, Acidobacteria, Lentisphaerae and Nitrospira were found only in the healthy coral samples. On the other hand, close to $70 \%$ of the microbiota of the diseased $M$. hispida consisted of Bacteroidetes (Fig. 1). This represented approximately 5-fold more Bacteroidetes in the diseased sample than in the Mh4 healthy sample. A relative increase of Deltaproteobacteria (5-fold) and Epsilonproteobacteria (4-fold) in the diseased sample compared to the Mh4 healthy sample (Fig. 1). Only $1 \%$ of the sequences from the 
diseased sample were not allocated to any phyla. Shanon diversity indexes (at 0.03 cut-off) were 3.59 for water, 2.06 and 3.16 for healthy Mh2 and Mh4, and 1.82 for diseased colony.

Most sequences of the coral mucus and water formed tight clusters, corresponding to species (Electronic Supplementary Material, Figs. S4, S5, S6, S7 and Table 1). Clusters were defined as at least three sequences having more than $97 \%$ similarity [37]. The dominant clusters in water were Cyanobacteria (W1), Alphaproteobacteria (W3) and unclassified bacteria (W14), corresponding to $34 \%$ of the sequences. The main clusters from healthy corals were Alphaproteobacteria (clusters H1, H2, M2, and M3), Bacteriodetes (cluster M1) and Firmicutes (cluster M5). The largest cluster in the diseased M. hispida (D2) represented $71 \%$ of the sequences $(N=208)$ and had $99 \%$ sequence similarity towards an unclassified Bacteroidetes sequence (Table 1). The second largest cluster (D1) had 16 sequences of Deltaproteobacteria and three clusters of the Firmicutes (D9, D10, and D11). A large fraction of the sequences from water (32\%), healthy (23\%) fell into singletons and double- tons, while most of the sequences from diseases $M$. hispida (96\%) formed clusters.

Representatives of the Bacteroidetes sequences found in the four libraries were aligned to other Bacteroidetes sequences retrieved from GenBank (i.e., type strains and other environmental bacteroidetes, including those associated to $M$. braziliensis). Using the same parameters already mentioned, a tree was generated (Electronic Supplementary Material, Fig. S8). Bacteroidetes found in the water are heterogeneous and well distributed along the tree. In contrast, Bacteroidetes associated with healthy and diseased M. hispida corals formed separated distinct and tight clusters. Bacteroidetes from the diseased coral were grouped in one single cluster. All sequences from the healthy corals (except six), formed a cluster separated from both water and diseased coral sequences.

The rarefaction curves indicated that the number of groups on higher taxonomic levels (i.e., order/class) found in the water, healthy, and diseased corals reached a plateau, between 30 and 50 (Fig. 2). However, the diversity at species level (defined by the threshold of $97 \%$ sequence
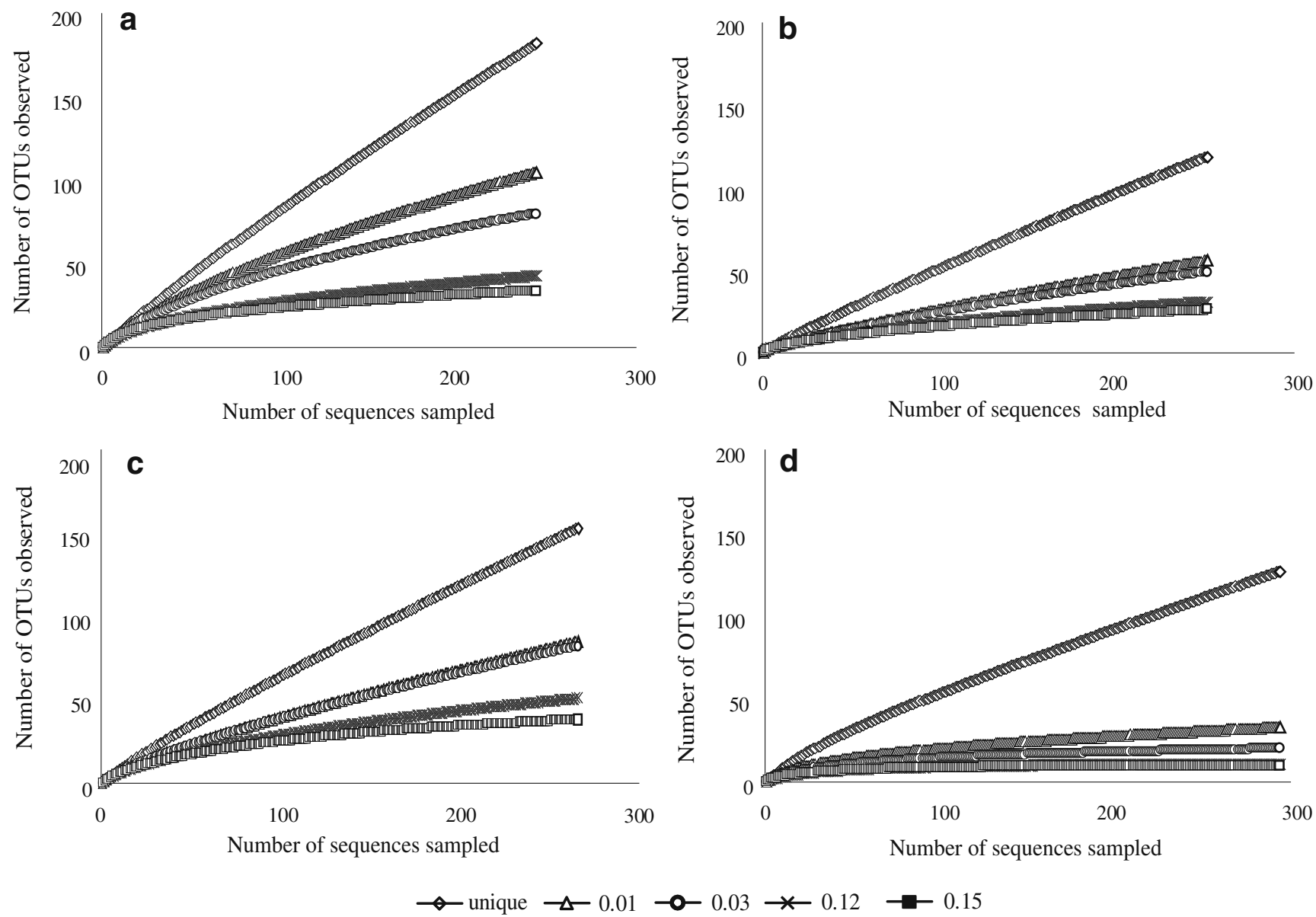

Figure 2 Rarefaction curves from DOTUR analysis of sequences from a sea water; b healthy MH2; $\mathbf{c}$ healthy MH4 and d diseased coral mucus $16 \mathrm{~S}$ rRNA gene library for various distance levels. Error bars representing a 95\% confidence interval were omitted for clarity 
similarity) did not reach an asymptote in this study. A total of $80,50,80$, and 20 species were determined for the water, healthy M. hispida Mh2 and Mh4, and diseased M. hispida, respectively (Fig. 2). Rarefaction curves using an evolutionary distance of $1 \%$ or $3 \%$ (both used to delimit species level diversity) showed a greater decrease in diversity in the diseased $M$. hispida, with reduction of almost $85 \%$ in the OTUs when compared to the "unique" sequences curve.

The comparison of the bacterial community 16S rRNA sequences of $M$. hispida, M. braziliensis and surrounding seawater by means of PCA showed that each coral species has a different microbiota (Fig. 3). J-Libshuff analysis with 10,000 randomizations corroborated the Principal Component Analysis (PCA) with a $p$ value $<0.0001$ (Electronic Supplementary Material, Fig. S9 online).

\section{Discussion}

Although 70-99\% of bacteria found in M. hispida and its surrounding water reaches at least $97 \%$ identity to sequences already deposited at GenBank, the majority of these sequences is not recognized to phyla or class levels with

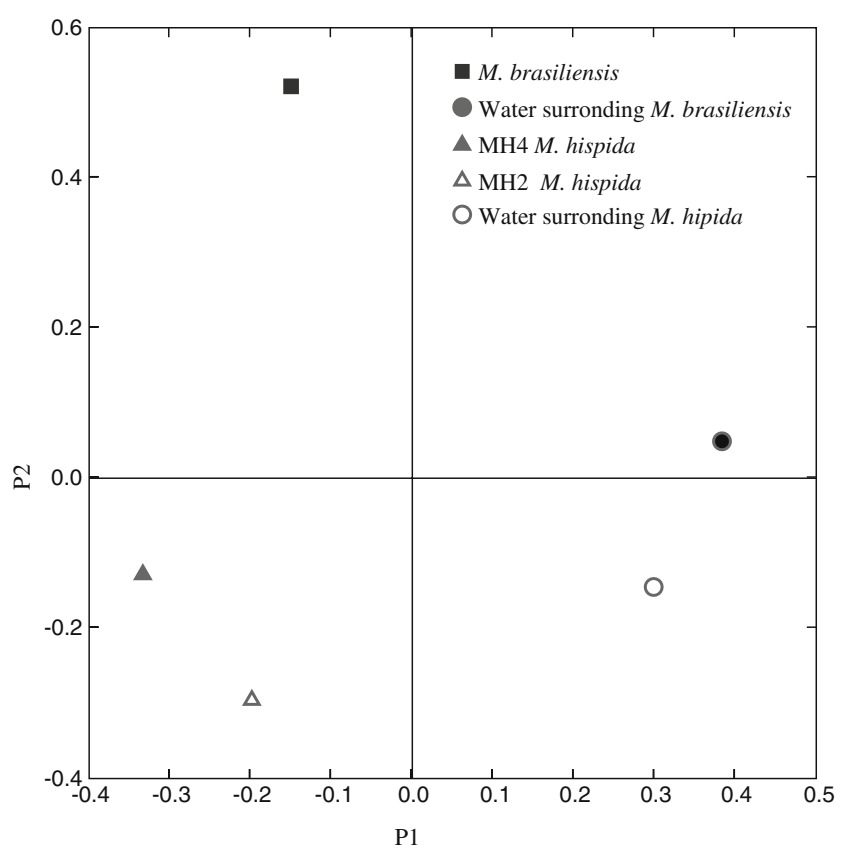

Figure 3 Principal coordinates analysis (PCA) using UniFrac software. 16S rRNA sequences of the $M$. hispida, M. braziliensis and water surrounding these coral samples were aligned using Muscle and $p$ distance model in the MEGA software was used to create a single phylogenetic tree containing all the sequences. This tree was used as input to UniFrac to analyze the relationships between theses samples using PCA. Black square, black circle, triangles and white circle represent $M$. braziliensis, water surrounding M. braziliensis, the two healthy $M$. hispida samples and the water surrounding $M$. hispida, respectively confidence (Fig. 1). This is a reflection of recent high throughput sequencing of $16 \mathrm{~S}$ rRNA using uncultured techniques that enriched the GenBank with "uncultured bacteria". This means that the microbial diversity is being recognized, but it remains not classified at lower taxonomic levels (i.e., order, family, and genus). This is evidenced in Table 1, where, from the 47 clusters found in total, 41 have at least $97 \%$ identity to some clone at GenBank. On the other hand, only five clones have more than $97 \%$ identity to a type strain, and 26 have less than $90 \%$ identity to a type strain.

The bacterial community of diseased M. hispida is dominated by a single Bacteroidetes species. The representative Bacteroidetes 16S rRNA sequence (38MH2D_PL4) appears to belong to a widely distributed bacteria, common in the environment, with close matches to sequences from previous studies of bacterioplankton from the Massachusets area [38] and to sequences from experimentally fossilized embryos of the Australian sea urchin Heliocidaris erythrogramma [39]. The genetic variability within the Bacteroidetes found in the present study is very low, probably restricted to one species (Figures S7, S8 online supplementary material). Most of the sequences had 98 to $99 \%$ similarity to the sequence EF 433144.1 and not to sequences retrieved by [40] (Table 1). The sequence EF 433144.1 originated from Faviid coral from the Northern Red Sea (Eilat) affected by black band disease [41]. Barneah and colleagues found that proportions of Bacteroidetes retrieved from tissue mucus layer adjacent to the black band was $5 \%$, increasing to $16 \%$ in the sample from the black band, but this group was not found when samples were retrieved from the mucus layer of the healthy tissue [41].

It is becoming evident that Bacteroidetes plays a role in coral health. Diseased tissues of Montastrea annularis have an increased number of Bacteroidetes sequences [42]. Bacteroidetes was also present in black band affected Siderastrea siderea [43] and in diseased Montipora aequitubecurlata [44]. More recently, a bioassay study using the coral Porites compressa and metagenomics of coral microbiota clearly demonstrated an increase in the Bacteroidetes group in stressed corals [40]. P. compressa exposed to reduced $\mathrm{pH}$ or nutrient enrichment had a 14-fold or 6-fold increase, respectively, in the relative amount of Bacteroidetes DNA sequences. Bioassays have not been performed to demonstrate the Koch's postulates (to establish a causal relationship between a causative microbe and a disease) in this case. Our study shows that Bacteroidetes found in the diseased $M$. hispida are different from Bacteroidetes present in the healthy colonies or in the seawater. This might suggest that bacteroidetes observed in the disease coral, colonized the sample after or during the disease, or, if they were present in the healthy condition, it was in a very low number." 
"Bacteroidetes appear to have several properties which allow them to be successful coral pathogens [45]. First, it tolerates high concentrations of salt and low levels of dissolved oxygen. Second, it has cell colonization factors (fimbrils) and produces very potent toxins, most notably zinc-metaloproteases that destroy cell junctions and promote the cleavage of e-cadherin possibly leading to cell death. The genomic plasticity and pathogenicity would be associated with horizontally acquired genetic elements (e. g., transposons). Third, Bacteroidetes are frequently associated to areas of high fecal content and the possible contamination of Corumbau reef by sewage may lead to unbalanced environmental conditions and proliferation of this bacterium in corals."

The microbiota of healthy M. hispida seems to be dominated by a diverse group of Proteobacteria, including putative gliding bacteria (cluster H2) related to Hirschia baltica IFAM 1418T, diazotrophic bacteria related to Azospirillum brasilensis (cluster H1), Flavobacterium frigoris (cluster M1) and Terasakiella pusilla (cluster M3). Several putative facultative anaerobic bacteria (e.g., Vibrio nereis, Arcobacter nitrofigilis, and Staphylococcus warneri) or micro-aerofilic bacteria (Propionibacterium avidum, Paenibacillus koreensis and Clostridium cylindrosporum) were also found in association with healthy $M$. hispida, although these sequences have low percent similarity with GenBank sequences suggesting that oxygen may be frequently depleted in the coral holobiont in spite of the zooxanthellae photosynthetic activity. During the night oxygen is depleted in the holobiont by the metabolic activity of the holobiont's heterotrophic community, including Bacteria, Archaea, and Eukaryotes [46]. Diazotrophic bacteria are commonly found in different types of corals. Cyanobacteria and putative diazotrophic were among the dominant groups in healthy $M$. braziliensis [23], possibly indicating a type of mutualistic relationship that is not well understood in this holobiont.

The PCA comparison of the M. braziliensis and $M$. hispida bacterial communities, both obtained from the Itacolomis reef, showed a species-specific pattern, forming separated groups. This analysis also indicated that the two bacterial communities of the surrounding seawater appeared together but separated from the corals. Both M. hispida samples were closer to each other than to M. braziliensis. The $\int$-LIBSHUFF test reinforced the differences in bacterial community composition observed in PCA (Electronic Supplementary Material, Fig. S9). J-LIBSHUFF is a powerful tool to detect differences between communities, providing the basis for ecological inferences about the association of microbial community composition [34, 47]. These results corroborate the studies on Montastraea franksi, Diploria strigosa, and Porites astreoides [6]. These corals shown marked species-specific patterns when indi- viduals more than $1,000 \mathrm{~km}$ apart from one another were analyzed, suggesting host-microbe co-evolution.

In order to identify lineages that are contributing to yield differences between samples that had been shown by the PCA, we performed a "Lineage-specific Analysis. Choosing a small distance, which cuts near from the root, we can perform analysis at about the phylum level (see "Materials and Methods"). There are three nodes that showed significant $\mathrm{G}$ test $p$ values, indicating that the node had an excess or deficit of sequences in each sample (data not shown). Two important nodes corresponding to $\alpha$-Proteobacteria and Bacteroidetes sequences were over-represented in $\mathrm{M}$. braziliensis. One important node consisting of Firmicutes members had only sequences in healthy $M$. hispida. This analysis suggested that $\alpha$-Proteobacteria, Bacteroidetes, and Firmicutes distinguishes the microbial communities between M. braziliensis and M. hispida.

Although there is a recently published paper with $M$. hispida from Buzios, Brazil [48] this is the first culture independent analysis of the bacterial community diversity of the reef builder $M$. hispida from Abrollos bank. This species is sympatric with M. braziliensis and yet it has possibly evolved to harbor a specific microbiota. Several recent studies have found a higher richness (greater number of OTUs) in diseased than in healthy corals [21, 23, 49]. Apparently, the loss of homeostasis allows the colonization of the holobionts by a diverse opportunistic bacterial community. Opportunistic microbes may take advantage of the compromised immune system of the coral host and proliferate in diseased colonies. Our study shows the opposite pattern with the dominance of one single bacterial species in the diseased coral. Our study also highlights the need for further bioassays in order to better understand the disease process in this coral species from the early onset of infection to the late disease stages.

Acknowledgements This work was supported by grants from FAPDF and CNPq. FLT also acknowledges grants from US Embassy, CNPq, IFS and FAPERJ. RLM and RBFF acknowledge grants from Conservation International. FLT, RLM, and RBFF acknowledge support of PROABROLHOS (no. 420219/2005-6). APC acknowledges a fellowship from CAPES.

\section{References}

1. Leão ZMAN, Kikuchi RKP (2005) A relic coral fauna threatened by global changes and human activities, Eastern Brazil. Mar Pollut Bull 51:599-611

2. Leão ZMAN, Kikuchi RKP, Testa T (2003) Corals and coral reefs of Brazil. In: Cortés J (ed) Latin American coral reefs. Elsevier Science, Amsterdam

3. Fukami H, Budd AF, Paulay G, Sole-Cava A, Allen Chen C, Iwao K, Knowlton N (2004) Conventional taxonomy obscures deep divergence between Pacific and Atlantic corals. Nature 427:832-835 
4. Nunes F, Fukami H, Vollmer SV, Norris RD, Knowlton N (2008) Re-evaluation of the systematics of the endemic coral of Brazil by molecular data. Coral Reefs 27:423-432

5. Alves N Jr, Maia Neto OS, Silva BSO, de Moura RL, FranciniFilho RB, Castro CB, Paranhos R, Blanche C, Bitner-Mathé BC, Kruger RH, Vicente ACP, Thompson CC, Thompson FL (2009) Diversity and pathogenic potential of vibrios isolated from Abrolhos Bank corals. Environmental Microbiology Reports 2:90-95

6. Rohwer F, Seguritan V, Azam F, Knowlton N (2002) Diversity and distribution of coral-associated bacteria. Mar Ecol Prog Ser 243:1-10

7. Rosenberg E, Koren O, Reshef L, Efrony R, Zilber-Rosenberg I (2007) The role of microorganisms in coral health, disease and evolution. Nat Rev Microbiol 5:355-362

8. Gardner TA, Côté IM, Gill JA, Grant A, Watkinson AR (2003) Long-term region-wide declines in Caribbean corals. Science 301:958-960

9. Bellwood DR, Hughes TP, Folke C, Nyström M (2004) Confronting the coral reef crisis. Nature 429:827-833

10. Crabbe MJC (2009) Scleractinian coral population size structures and growth rates indicate coral resilience on the fringing reefs of North Jamaica. Mar Environ Res 67:189-198

11. Francini-Filho RB, Moura RL, Thompson FL, Reis RM, Kaufman L, Kikuchi RKP, Leão ZMAN (2008) Diseases leading to accelerated decline of reef corals in the largest South Atlantic reef complex (Abrolhos Bank, eastern Brazil). Mar Pollut Bull 56:1008-1014

12. Reshef L, Koren O, Loya Y, Zilber-Rosenberg I, Rosenberg E (2006) The coral probiotic hypothesis. Environ Microbiol 8:20682073

13. Ritchie KB (2006) Regulation of microbial populations by coral surface mucus and mucus-associated bacteria. Mar Ecol Prog Ser 322:1-1

14. Sorokin YI (1973) Trophical Role of Bacteria in the Ecosystem of the Coral Reef. Nature 242:415-417

15. Sorokin YI (1978) Microbial production in the coral-reef community. Arch Hydrobiol 83:281-323

16. Anthony KRN (1999) Coral suspension feeding on fine particulate matter. J Exp Mar Biol Ecol 232:85-106

17. Anthony KRN, Fabricius KE (2000) Shifting roles of heterotrophy and autotrophy in coral energetics under varying turbidity. $\mathrm{J}$ Exp Mar Biol Ecol 252:221-253

18. Anthony KRN (2000) Enhanced particle-feeding capacity of corals on turbid reefs (Great Barrier Reef, Australia). Coral Reefs 19:59-67

19. Rosenfeld M, Bresler V, Abelson A (1999) Sediment as a possible source of food for corals. Ecol Lett 2:345-348

20. Littman RA, Willis BL, Pfeffer C, Bourne DG (2009) Diversities of coral-associated bacteria differ with location, but not species, for three acroporid corals on the Great Barrier Reef. FEMS Microbiol Ecol 68:152-163

21. Bourne D, Iida Y, Uthicke S, Smith-Keune C (2008) Changes in coral-associated microbial communities during a bleaching event. ISME J 2:350-363

22. Shnit-Orland M, Kushmaro A (2009) Coral mucus-associated bacteria: a possible first line of defense. FEMS Microbiol Ecol 67:371-380

23. Reis AMM, Araújo SD, Moura RL, Francini-Filho RB, Pappas G, Coelho AMA, Krüger RH, Thompson FL (2009) Bacterial diversity associated with the Brazilian endemic reef coral Mussismilia braziliensis. J Appl Microbiol 106:1378-1387

24. Eaton AD, Clesceri LS, Greenberg AE, Franson MAH, American Public Health A, American Water Works A, Water Environment F (1995) Standard methods for the examination of water and wastewater. American Public Health Association, Washington, DC
25. Schauer M, Massana R, Pedros-Alio C (2000) Spatial differences in bacterioplankton composition along the Catalan coast (NW Mediterranean) assessed by molecular fingerprinting. FEMS Microbiol Ecol 33:51-59

26. Pappas GJ, Benabdellah K, Zingales B, González A (2005) Expressed sequence tags from the plant trypanosomatid Phytomonas serpens. Mol Biochem Parasitol 142:149-157

27. Cole JR, Chai B, Farris RJ, Wang Q, Kulam-Syed-Mohideen AS, McGarrell DM, Bandela AM, Cardenas E, Garrity GM, Tiedje JM (2007) The ribosomal database project (RDP-II): introducing myRDP space and quality controlled public data. Nucleic Acids Research 35:D169-D172

28. Edgar RC (2004) MUSCLE: multiple sequence alignment with high accuracy and high throughput. Nucleic Acids Res 32:17921797

29. Schloss PD, Handelsman J (2005) Introducing DOTUR, a computer program for defining operational taxonomic units and estimating species richness. Appl Environ Microbiol 71:15011506

30. Tamura K, Dudley J, Nei M, Kumar S (2007) MEGA4: Molecular Evolutionary Genetics Analysis (MEGA) software version 4.0. Mol Biol Evol 24:1596-1599

31. Saitou N, Nei M (1987) The neighbor-joining method: a new method for reconstructing phylogenetic trees. Mol Biol Evol 4:406-425

32. Lozupone C, Hamady M, Knight R (2006) UniFrac - an online tool for comparing microbial community diversity in a phylogenetic context. BMC Bioinformatics 7:371-371

33. Krzanowski WJ (2000) Principles of multivariate analysis. A User's perspective. Oxford University Press, Oxford

34. Schloss PD, Larget BR, Handelsman J (2004) Integration of microbial ecology and statistics: a test to compare gene libraries. Appl Environ Microbiol 70:5485-5492

35. Altschul SF, Gish W, Miller W, Myers EW, Lipman DJ (1990) Basic local alignment search tool. J Mol Biol 215:403-410

36. Maidak BL, Cole JR, Parker CT, Garrity GM, Larsen N, Li B, Lilburn TG, McCaughey MJ, Olsen GJ, Overbeek R, Pramanik S, Schmidt TM, Tiedje JM, Woese CR (1999) A new version of the RDP (Ribosomal Database Project). Nucleic Acids Res 27:171173

37. Stackebrandt E, Frederiksen W, Garrity GM, Grimont PAD, Kämpfer P, Maiden MCJ, Nesme X, Rosselló-Mora R, Swings J, Trüper HG, Vauterin L, Ward AC, Whitman WB (2002) Report of the ad hoc committee for the re-evaluation of the species definition in bacteriology. Int J Syst Evol Microbiol 52:1043-1047

38. Acinas SG, Klepac-Ceraj V, Hunt DE, Pharino C, Ceraj I, Distel DL, Polz MF (2004) Fine-scale phylogenetic architecture of a complex bacterial community. Nature 430:551-554

39. Raff EC, Schollaert KL, Nelson DE, Donoghue PCJ, Thomas C-W, Turner FR, Stein BD, Dong $\mathrm{X}$, Bengtson S, Huldtgren $\mathrm{T}$, Stampanoni M, Chongyu Y, Raff RA (2008) Embryo fossilization is a biological process mediated by microbial biofilms. Proc Natl Acad Sci USA 105:19360-19365

40. Thurber RV, Willner-Hall D, Rodriguez-Mueller B, Desnues C, Edwards RA, Angly F, Dinsdale E, Kelly L, Rohwer F (2009) Metagenomic analysis of stressed coral holobionts. Environ Microbiol 11:2148-2163

41. Barneah O, Ben-Dov E, Kramarsky-Winter E, Kushmaro A (2007) Characterization of black band disease in Red Sea stony corals. Environ Microbiol 9:1995-2006

42. Pantos O, Cooney RP, Le Tissier MDA, Barer MR, O'Donnell AG, Bythell JC (2003) The bacterial ecology of a plague-like disease affecting the Caribbean coral Montastrea annularis. Environ Microbiol 5:370-382

43. Sekar R, Mills DK, Remily ER, Voss JD, Richardson LL (2006) Microbial communities in the surface mucopolysaccharide layer 
and the black band microbial mat of black band-diseased Siderastrea siderea. Appl Environ Microbiol 72:5963-5973

44. Jones RJ, Bowyer J, Hoegh-Guldberg O, Blackall LL (2004) Dynamics of a temperature-related coral disease outbreak. Mar Ecol Prog Ser 281:63-77

45. Sears CL (2009) Enterotoxigenic Bacteroides fragilis: a rogue among symbiotes. Clin Microbiol Rev 22:349-369, Table of contents

46. Houlbreque F, Ferrier-Pages C (2009) Heterotrophy in tropical scleractinian corals. Biol Rev Camb Philos Soc 84:1-17

47. Singleton DR, Furlong MA, Rathbun SL, Whitman WB (2001) Quantitative comparisons of $16 \mathrm{~S}$ rRNA gene sequence libraries from environmental samples. Appl Environ Microbiol 67:43744376

48. Lins-de-Barros MM, Vieira RP, Cardoso AM, Monteiro VA, Turque AS, Silveira CB, Albano RM, Clementino MM, Martins OB (2009) Archaea, bacteria, and algal plastids associated with the reefbuilding corals Siderastrea stellata and Mussismilia hispida from Buzios, South Atlantic Ocean, Brazil. Microb Ecol. doi:10.1007/ s00248-009-9612-y

49. Sunagawa S, DeSantis TZ, Piceno YM, Brodie EL, DeSalvo MK, Voolstra CR, Weil E, Andersen GL, Medina M (2009) Bacterial diversity and White Plague Disease-associated community changes in the Caribbean coral Montastraea faveolata. ISME J 3:512-521 